\title{
Effect of Localized Temperature Difference on Hydrogen Fermentation
}

\author{
Seongwon Im ${ }^{1}$, Mo-Kwon Lee ${ }^{1,2}$, Alsayed Mostafa ${ }^{1}{ }^{(0)}$, Om Prakash ${ }^{1}{ }^{(D}$, Kyeong-Ho Lim $^{3}$ and Dong-Hoon Kim ${ }^{1, *}$ \\ 1 Department of Smart-City Engineering, Inha University, 100 Inharo, Michuhol-gu, Incheon 22212, Korea; \\ deback3838@naver.com (S.I.); mklee@hit.ac.kr (M.-K.L.); ama_mostafa@ymail.com (A.M.); \\ opky72@yahoo.in (O.P.) \\ 2 Department of Environmental Health, Daejeon Health Institute of Technology, 21 Chungjeong-ro, Dong-gu, \\ Daejeon 34504, Korea \\ 3 Department of Civil and Environmental Engineering, Kongju National University, Cheonan, \\ Chungnam 31080, Korea; khlim@kongju.ac.kr \\ * Correspondence: dhkim77@inha.ac.kr; Tel.: +82-10-2639-9379; Fax: +82-32-873-7560
}

Citation: Im, S.; Lee, M.-K.;

Mostafa, A.; Prakash, O.; Lim, K.-H.; Kim, D.-H. Effect of Localized Temperature Difference on Hydrogen Fermentation. Energies 2021, 14, 6885. https://doi.org/10.3390/en14216885

Academic Editor: Ijung Kim

Received: 21 September 2021

Accepted: 19 October 2021

Published: 20 October 2021

Publisher's Note: MDPI stays neutral with regard to jurisdictional claims in published maps and institutional affiliations.

Copyright: (c) 2021 by the authors. Licensee MDPI, Basel, Switzerland. This article is an open access article distributed under the terms and conditions of the Creative Commons Attribution (CC BY) license (https:// creativecommons.org/licenses/by/ $4.0 /)$.

\begin{abstract}
In a lab-scale bioreactor system, (20 L of effective volume in our study) controlling a constant temperature inside bioreactor with a total volume $25 \mathrm{~L}$ is a simple process, whereas it is a complicated process in the actual full-scale system. There might exist a localized temperature difference inside the reactor, affecting bioenergy yield. In the present work, the temperature at the middle layer of bioreactor was controlled at $35{ }^{\circ} \mathrm{C}$, while the temperature at top and bottom of bioreactor was controlled at $35 \pm 0.1, \pm 1.5, \pm 3.0$, and $\pm 5.0^{\circ} \mathrm{C}$. The $\mathrm{H}_{2}$ yield of $1.50 \mathrm{~mol} \mathrm{H}_{2} / \mathrm{mol}$ hexose ${ }_{\text {added }}$ was achieved at \pm 0.1 and $\pm 1.5^{\circ} \mathrm{C}$, while it dropped to 1.27 and $0.98 \mathrm{~mol} \mathrm{H}_{2} / \mathrm{mol}$ hexose $e_{\text {added }}$ at \pm 3.0 and $\pm 5.0^{\circ} \mathrm{C}$, respectively, with an increased lactate production. Then, the reactor with automatic agitation speed control was operated. The agitation speed was $10 \mathrm{rpm}$ (for $22 \mathrm{~h}$ ) under small temperature difference $\left(< \pm 1.5^{\circ} \mathrm{C}\right)$, while it increased to $100 \mathrm{rpm}$ (for $2 \mathrm{~h}$ ) when the temperature difference between top and bottom of reactor became larger than $\pm 1.5^{\circ} \mathrm{C}$. Such an operation strategy helped to save $28 \%$ of energy requirement for agitation while producing a similar amount of $\mathrm{H}_{2}$. This work contributes to facilitating the upscaling of the dark fermentation process, where appropriate agitation speed can be controlled based on the temperature difference inside the reactor.
\end{abstract}

Keywords: temperature difference; $\mathrm{H}_{2}$ fermentation; agitation speed; energy requirement

\section{Introduction}

The development of hydrogen $\left(\mathrm{H}_{2}\right)$ production technology has gained significant attention due to its high energy content $(142 \mathrm{~kJ} / \mathrm{g})$ and its cleaner nature on combustion [1-3]. At present, the commercial production of $\mathrm{H}_{2}$ is achieved via coal gasification, gas reforming, etc., which are not sustainable and environmentally benign due to the depletion of the fossil fuels and the generation of greenhouse gaseous emissions [4,5]. On the other hand, water splitting technology and biologically mediated ways could provide a sustainable way of producing $\mathrm{H}_{2}$ [6,7]. Among various bio- $\mathrm{H}_{2}$ production routes, the production of green hydrogen by use of organic wastes as feedstock has a huge potential to become an important source of hydrogen in the future if operating under ambient temperature and pressure conditions. Dark fermentative $\mathrm{H}_{2}$ production (in short "dark fermentation"), in particular, is considered an environmentally friendly and practically suitable process for commercial bio- $\mathrm{H}_{2}$ production, due to its high production rate, simple operation, and handling of various organic wastes [8-12].

There are various factors, such as $\mathrm{pH}$, temperature, substrate types and lactic acid contamination can affect the $\mathrm{H}_{2}$ fermentation performance [13-16]. Among them, temperature is a critical operational factor, since it influences the microbial growth, enzymatic activity, and population dynamics $[17,18] . \mathrm{H}_{2}$ production in the dark fermentation process 
is conducted with various temperature regimes from mesophilic to hyper-thermophilic conditions. It has been reported that keeping a constant temperature in an appropriate range of $35-40{ }^{\circ} \mathrm{C}$ is important in mesophilic $\mathrm{H}_{2}$ fermentation, whereas fluctuations in temperature beyond the optimal range negatively affected the performance [18]. The detailed heterogenous temperature profile was not reported, but it can reach up to $2-5^{\circ} \mathrm{C}$ in the full-scale anaerobic digester [19].

The agitation intensity is reported to enhance the bioenergy yield by providing a sufficient environment for the nutrient transfer to the microorganisms, heat transfer, and release of the produced biogas from the digestate mixture [20]. However, the energy consumption for the agitation intensity is reported to be up to $50 \%$ of the overall energy input of the wastewater treatment process [21]. The application of intermittent and short mixing strategy was considered as an alternative option over continuous stirring to cut down the energy cost and even to improve the biogas yield [22]. Although several strategies were employed previously to study the impact of mixing in the wastewater treatment process, there is no rule of thumb regarding the agitation or recycling intensity required for stable reactor operation. Besides, the temperature variations inside the bioreactor (top, middle, and bottom) layer are a crucial factor to be considered for applying the agitation intensity for better mixing and reducing the energy input of the wastewater treatment process. Moreover, the information about the agitation intensity on dark fermentation was rarely reported [23]. To the author's knowledge, the effects of localized temperature differences inside the bioreactor on $\mathrm{H}_{2}$ production have never been reported.

Based on the above, the aim of this study was to investigate the effect of localized temperature difference $\left( \pm 1.5\right.$ to $\left.\pm 5^{\circ} \mathrm{C}\right)$ inside the reactor on dark fermentation. The temperature difference was generated by using water jackets to maintain a different temperature continuously, as shown in the schematic diagram (Figure 1). Furthermore, flux balance analysis (FBA) was employed to understand the mechanism for enhancement. The energy demand for agitation was also assessed using the operational strategy of stirring speed control responding to the temperature gap.

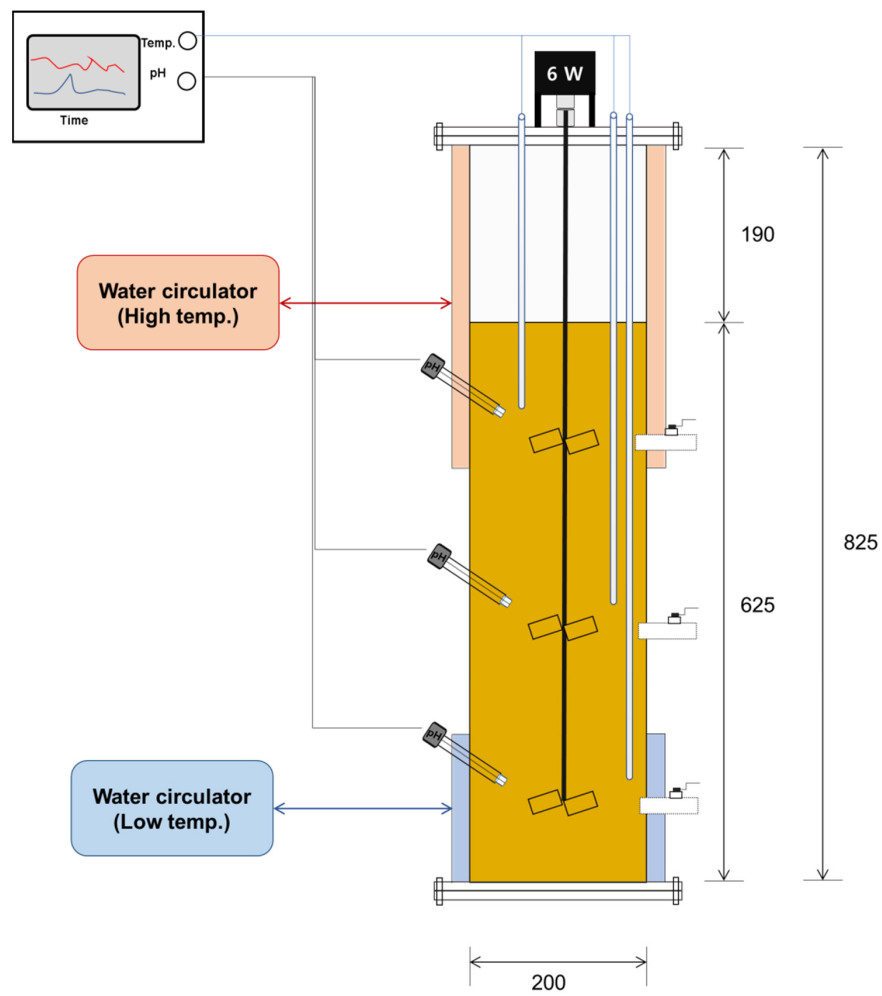

Figure 1. A schematic diagram of bioreactor system used in this study. 


\section{Materials and Methods}

\subsection{Inoculum and Substrate}

The inoculum for $\mathrm{H}_{2}$ fermentation was collected from an anaerobic digester in a local wastewater treatment plant in Korea. The $\mathrm{pH}$, and volatile suspended solids (VSS) concentration of the sludge were 7.5 , and $25.0 \mathrm{~g} / \mathrm{L}$, respectively. The sludge was filtered through a $2.0 \mathrm{~mm}$ sieve to remove large particles, and then heat-treated at $90{ }^{\circ} \mathrm{C}$ for 20 min to inactive methanogenic activity [24]. Glucose was used as a substrate and the concentration was adjusted to $10 \mathrm{~g}$ chemical oxygen demand (COD)/L. Nutrients were supplied according to COD:N:P:Fe ratio of 100:5:1:0.33 by using $\mathrm{NH}_{4} \mathrm{Cl}, \mathrm{KH}_{2} \mathrm{PO}_{4}$, $\mathrm{FeCl}_{2} \cdot 4 \mathrm{H}_{2} \mathrm{O}$. To minimize the effects of trace metal deficiency, various trace metals were added as follows (in mg. $\mathrm{L}^{-1}$ ): $\mathrm{Na}_{2} \mathrm{MoO}_{4} 4 \mathrm{H}_{2} \mathrm{O}, 5 ; \mathrm{H}_{3} \mathrm{BO}_{3}, 50, \mathrm{MnCl}_{2} 4 \mathrm{H}_{2} \mathrm{O}, 50 ; \mathrm{ZnCl}_{2}, 50$; $\left.\mathrm{CuCl}_{2}, 30 ; \mathrm{NiCl}_{2} 6 \mathrm{H}_{2} \mathrm{O}, 92 ; \mathrm{CoCl}_{2} 6 \mathrm{H}_{2} \mathrm{O}, 50 ; \mathrm{Na}_{2} \mathrm{SeO}_{3}, 50\right)$ [25].

\subsection{Experiment}

Batch experiments were conducted using a completely stirred tank reactor with a working volume of $20 \mathrm{~L}$ (200 mm ID), controlled at $35 \pm 0.1^{\circ} \mathrm{C}$ (Figure 1). The heat-treated sludge was inoculated in the reactor at a VSS concentration of $10.0 \mathrm{~g} / \mathrm{L}$. After seeding with media and substrate addition, the reactor was purged by $\mathrm{N}_{2}$ gas (99.99\%) for 10 min to establish an anaerobic condition. The $\mathrm{pH}$ inside the reactor was controlled at $6.0 \pm 0.1$ using a pH sensor (APH-200VD, South Korea), pH controller (samsnK.com-96pH(ORP)L4, South Korea). The temperature was measured by temperature sensor (TC-V, range (-)50-300 ${ }^{\circ} \mathrm{C}$, accuracy $\pm 3 \%$, South Korea) and maintained by a water bath circulator equipped with built-in water jacket. Experiments were conducted to investigate the effects of localized temperature difference in a stirred tank reactor on dark fermentation: control $\left(35 \pm 0.1^{\circ} \mathrm{C}\right), \mathrm{E} 1\left(35 \pm 1.5^{\circ} \mathrm{C}\right), \mathrm{E} 2\left(35 \pm 3.0^{\circ} \mathrm{C}\right), \mathrm{E} 3\left(35 \pm 5.0^{\circ} \mathrm{C}\right)$. The temperature variation was generated by using water jackets (CW10G) filled with cool and hot water at certain degrees to maintain a different temperature. For example, in the case of E3, the temperature of the bottom part of the reactor was adjusted to $30^{\circ} \mathrm{C}$, the middle part was $35^{\circ} \mathrm{C}$, and the top part was $40^{\circ} \mathrm{C}$, by circulating cool water $\left(10^{\circ} \mathrm{C}\right)$ at the bottom, and hot water $\left(42{ }^{\circ} \mathrm{C}\right)$ at the top at the pumping rate of $10 \mathrm{~L} / \mathrm{min}$. In addition, the $\mathrm{E} 4$ experiment was performed to compare the energy required for agitation speed. The agitation speed was $10 \mathrm{rpm}$ under small temperature difference $\left(< \pm 1.5^{\circ} \mathrm{C}\right.$ ) (for $22 \mathrm{~h}$ ), while it was increased to $100 \mathrm{rpm}$ (for $2 \mathrm{~h}$ ) when the temperature gap between top and bottom of reactor became larger than $\pm 1.5^{\circ} \mathrm{C}$. When the temperature cross over was more than $36.5^{\circ} \mathrm{C}$, the sensor activates stirring to $100 \mathrm{rpm}$. To rotate the broth, a $6 \mathrm{~W}$ AC induction speed control motor (Brand: SPG Motor, Model: S6I06GB-V12) was used. The power consumption was measured using a digital power meter. At the end of the experiment, samples were taken from the top, middle, and bottom of the reactor to analyze carbohydrates and organic acids.

\subsection{Analysis}

The concentrations of VSS and COD were measured according to Standard Methods [26]. We settled the sludge for 1 day, and then after pretreatment, such as heating evaporates most of the water present in the sludge. The glucose concentration was measured by the colorimetric method, as previously described [27]. The amount of produced biogas from the reactor was determined by water displacement method and was adjusted to the standard conditions of temperature $\left(0{ }^{\circ} \mathrm{C}\right)$ and pressure $(760 \mathrm{mmHg})(\mathrm{STP})$. The $\mathrm{H}_{2}$ and $\mathrm{CO}_{2}$ content in the biogas was measured by gas chromatography (GC, Gow Mac series 580) equipped with a thermal conductivity detector (TCD) using mole-sieve 5A and porapack Q (80/100 mesh) as a separation column. $\mathrm{N}_{2}$ gas $(99.99 \%)$ was used as a carrier gas with a flow rate of $30 \mathrm{~mL} / \mathrm{min}$ and the temperatures of injector, detector, and column were kept at 70,50 , and $80^{\circ} \mathrm{C}$, respectively.

Liquid samples obtained from the reactor were diluted 10 times with distilled water and filtered through 0.2 um pore size syringe filter to analyze soluble carbohydrate, and organic acids. Organic acids such as lactate, formate, acetate, propionate, and butyrate 
were analyzed by a high-performance liquid chromatograph (HPLC) (LC-20A series, SHIMADZU Co.) with an ultraviolet (215 nm) detector (UV1000, SHIMADZU) and an Aminex fast acid analysis column (HPX-87H, Bio-Rad Lab.). The mobile phase was $0.005 \mathrm{M} \mathrm{H}_{2} \mathrm{SO}_{4}$ applied at a $0.6 \mathrm{~mL} / \mathrm{min}$ flow rate and the temperatures of detector, oven, and column were 40,35 , and $90^{\circ} \mathrm{C}$, respectively. The flux balance analysis (FBA) model, previously developed by Chaganti et al. [28], was applied for experimental data analysis. The steps we followed for FBA, and the utilized abbreviations were the same as those stated in previous studies [28,29]. The goal of applying FBA was to investigate whether the reutilization of $\mathrm{H}_{2}$ for acetate production, i.e., acetogenic $\mathrm{H}_{2}$ consumption, varies among batches or not. FBA basically considers that acetate can be produced from two possible reactions, i.e., (i) acetyl coA, and (ii) $\mathrm{H}_{2}$ reaction with $\mathrm{CO}_{2}$. For FBA calculation, a $(30 \times 30)$ matrix was used. The numbers of intracellular, and extracellular reactions were 14, and 16, respectively. For solving the metabolic network linear equations, MetaFluxNet software (Version 1.8.6.2) was adopted. Further details regarding FBA can be found in previous studies [28,29]. The Pearson correlation coefficient was calculated to measure linear correlation between organic acid and $\mathrm{H}_{2}$ production.

\section{Results and Discussion}

\subsection{Fermentation Performance}

The temperature variations at the different heights of the bioreactor are depicted in Figure 2. Within $5 \mathrm{~h}$, the temperature at the middle layer became around $35^{\circ} \mathrm{C}$, while the temperature at the top and bottom reached $35 \pm 1.5, \pm 3.0$, and $\pm 5^{\circ} \mathrm{C}$, depending on the operational conditions. This indicates that the control of temperature and pumping rate of cool and hot water circulating reactor surface was successful to make localized temperature difference as planned. In addition, $\mathrm{pH}$ difference in three parts (top, middle, and bottom) was negligible (data not shown), indicating that $100 \mathrm{rpm}$ agitation speed was enough to provide sufficient mass transfer of soluble matters through the whole region of the bioreactor.
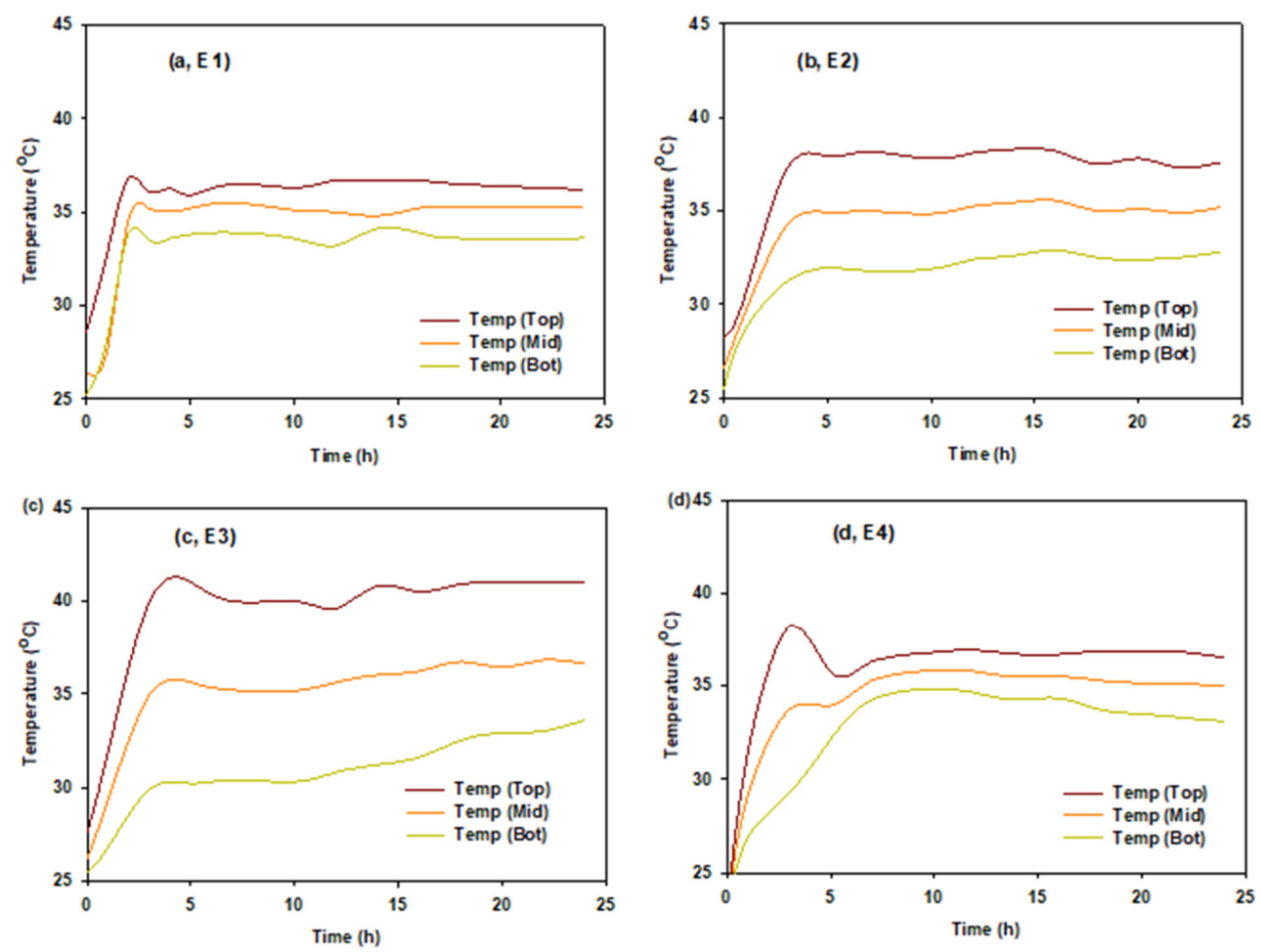

Figure 2. The change of temperature at top, middle, and bottom layer of reactor planned to deviate at (a) $\mathrm{E} 1\left(35 \pm 1.5^{\circ} \mathrm{C}\right)$, (b) E2 $\left(35 \pm 3.0^{\circ} \mathrm{C}\right)$, (c) E3 $\left(35 \pm 5.0^{\circ} \mathrm{C}\right)$, and (d) E4 $\left(35 \pm 1.5^{\circ} \mathrm{C}\right)$ during $\mathrm{H}_{2}$ fermentation. 
The total amount of $\mathrm{H}_{2}$ production declined as the temperature gap between top and bottom became larger (Figure 2). The $\mathrm{H}_{2}$ yield of $1.50 \mathrm{~mol} \mathrm{H}_{2} / \mathrm{mol}_{\text {hexose }}$ added was achieved at \pm 0.1 and $\pm 1.5{ }^{\circ} \mathrm{C}$, while it dropped to 1.27 and $0.98 \mathrm{~mol} \mathrm{H}_{2} / \mathrm{mol}$ hexose $\mathrm{added}_{\text {at }}$ \pm 3.0 and $\pm 5.0^{\circ} \mathrm{C}$, respectively (Figure 3 ). The temperature difference inside the bioreactor also affected the substrate removal efficiency and biomass growth. Glucose removal efficiency ranged 83 to $92 \%$ where the highest removal was observed in the control $\left( \pm 0.1{ }^{\circ} \mathrm{C}\right)$, and the lowest value was attained at $\pm 5.0^{\circ} \mathrm{C}$. Ranges of removal efficiency and $\mathrm{H}_{2}$ yield are near to the ranges previously stated in literature [30,31]. After fermentation, biomass concentration increased from (initial) $10 \mathrm{~g} \mathrm{VSS} / \mathrm{L}$ to $10.7 \mathrm{~g} \mathrm{VSS} / \mathrm{L}$ at the control $\left( \pm 0.1{ }^{\circ} \mathrm{C}\right)$, whereas at the temperature variations of $\pm 1.5, \pm 3.0$ and $\pm 5.0^{\circ} \mathrm{C}$ it increased to $10.4-10.6 \mathrm{~g}$ VSS/L. However, the difference in these two parameters did not seem great enough to tell the difference in $\mathrm{H}_{2}$ production performance. This is because those two parameters can vary, while the $\mathrm{H}_{2}$ production performance can be almost the same, and vice versa [32] Further, the increase in removal efficiency did not always lead to increased $\mathrm{H}_{2}$ productivity $[33,34]$. In addition, both the removal efficiency and biomass concentration were found to be microbially community dependent [35].
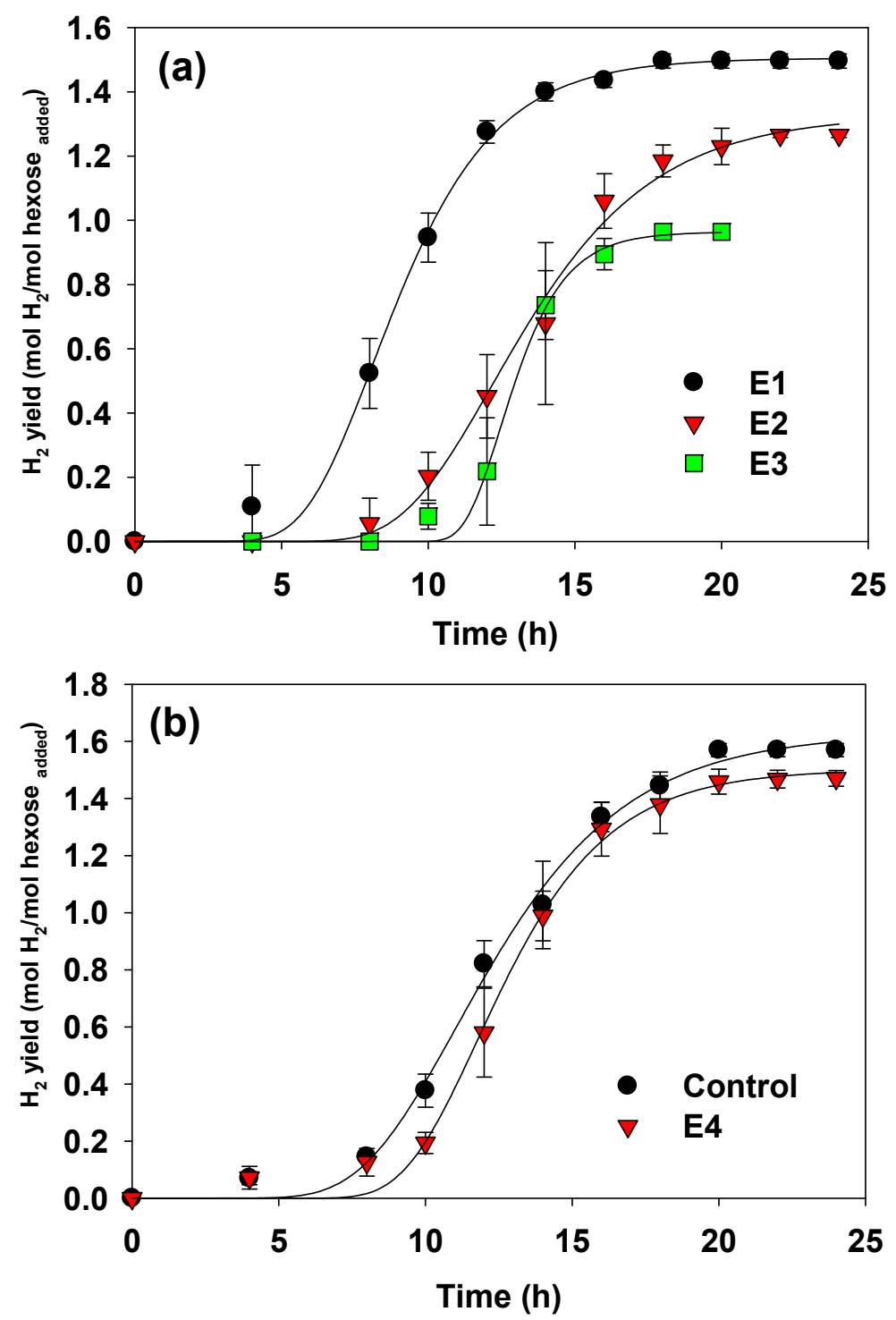

Figure 3. Cumulative $\mathrm{H}_{2}$ yield for $(\mathbf{a}) \mathrm{E} 1\left(35 \pm 1.5^{\circ} \mathrm{C}\right), \mathrm{E} 2\left(35 \pm 3.0^{\circ} \mathrm{C}\right), \mathrm{E} 3\left(35 \pm 5.0^{\circ} \mathrm{C}\right)$, (b) control $\left(35 \pm 0.1^{\circ} \mathrm{C}\right)$, and $\mathrm{E} 4\left(35 \pm 1.5^{\circ} \mathrm{C}\right)$ batches. 
Figure 4 shows the organic acids production profile under various temperature fluctuations. There was a slight difference in the carbohydrate and organic acid concentration in the samples taken from the reactor at the top, middle, and bottom. There was a slight difference (standard deviation $<1 \%$ ) in the carbohydrate and organic acid concentration in the samples taken from the reactor at the top, middle, and bottom. These results implied that the dissolved contents inside the reactor were mixed well during $\mathrm{H}_{2}$ experiment.

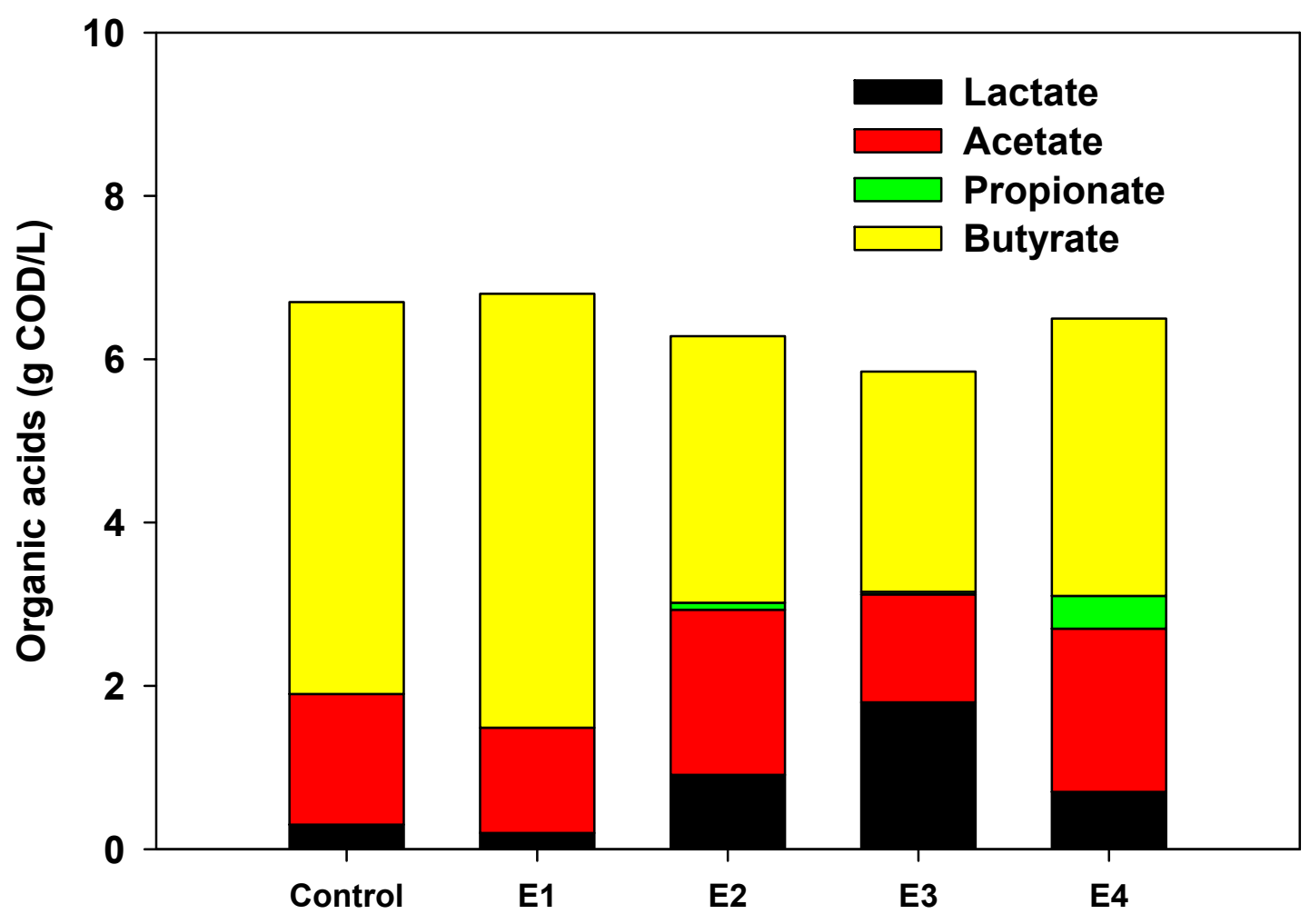

Figure 4. Organic acids profile for control $\left(35 \pm 0.1{ }^{\circ} \mathrm{C}\right), \mathrm{E} 1\left(35 \pm 1.5^{\circ} \mathrm{C}\right), \mathrm{E} 2\left(35 \pm 3.0^{\circ} \mathrm{C}\right), \mathrm{E} 3\left(35 \pm 5.0^{\circ} \mathrm{C}\right)$, and E4 $\left(35 \pm 1.5^{\circ} \mathrm{C}\right)$ batches.

The propionate concentration was negligible. The total organic acids production of $6.7 \mathrm{~g} \mathrm{COD} / \mathrm{L}$ was observed at the control experiment $\left( \pm 0.1^{\circ} \mathrm{C}\right)$, and a similar trend of organic acids accumulation was noted at the experimental condition at $\pm 1.5^{\circ} \mathrm{C}$. The organic acids production was dropped to 6.3 and $5.9 \mathrm{~g} \mathrm{COD} / \mathrm{L}$ at \pm 3.0 and $\pm 5.0^{\circ} \mathrm{C}$. The major organic acids production during the experimental conditions was acetate, butyrate, and lactate, while formate was not detected.

Butyrate was the major dominant metabolic product for all conditions, and higher concentrations of 4.80 and $5.31 \mathrm{~g} \mathrm{COD} / \mathrm{L}$ were observed at control and $\pm 1.5^{\circ} \mathrm{C}$, respectively. On the other hand, it dropped to 3.26 and $2.70 \mathrm{~g} \mathrm{COD} / \mathrm{L}$ at \pm 3.0 and $\pm 5.0^{\circ} \mathrm{C}$, respectively. The accumulation of lactate was limited at the control $35 \pm 0.1{ }^{\circ} \mathrm{C}$ and $\pm 1.5^{\circ} \mathrm{C}$, whereas the concentration was higher at \pm 3.0 and $\pm 5.0^{\circ} \mathrm{C}$. The localized temperature difference inside the reactor could affect organic acids distribution pattern (Figure 4). A maximum lactate accumulation of $1.8 \mathrm{~g} \mathrm{COD} / \mathrm{L}$ was observed at $\pm 5.0^{\circ} \mathrm{C}$. As indicated earlier, the lactate production is not beneficial for $\mathrm{H}_{2}$ production, which is mainly produced by lactic acid bacteria [36,37]. Further, previous study confirmed that the more lactate production, the less $\mathrm{H}_{2}$ that would be generated [38]. The possible suggestion to overcome this problem has been mentioned by culturing lactate utilizing hydrogen producing bacteria (LU-HPB) such as Megasphaera elsedenii [16]. Experimental results were found to match with statistical analysis. In specific, a high positive correlation was observed between $\mathrm{H}_{2}$ yield and $\mathrm{HBu}$ generation, (Pearson's $r$ value of +0.920 ). On the other hand, $\mathrm{H}_{2}$ yield inversely correlated with HLa production (Pearson's r value of -0.999 ). 
Energy balance on a COD basis and molar conversion for batches under various localized temperature differences are provided in Table S1 (see Supplementary Material). The considered fractions were acetate, butyrate, propionate, lactate, $\mathrm{H}_{2}$, biomass, and residual glucose content. The fraction of biomass was calculated by the change in VSS content, whereas the molecular formula was assumed to be $\left(\mathrm{C}_{5} \mathrm{H}_{7} \mathrm{O}_{2} \mathrm{~N}\right)$. For all batches, the total sum was higher than $89.6 \%$, referring to the accuracy of analysis. In all batches, the highest portion of energy distribution was assigned to butyrate. On the other hand, residual glucose molar conversion varied among batches, whereas it reached its maximal value of $0.17 \mathrm{~mol} \mathrm{H}_{2} / \mathrm{mol}$ hexose $e_{\text {added }}$ in E3. For further understanding of the $\mathrm{H}_{2}$ production performance, we calculated acetogenic $\mathrm{H}_{2}$ consumption by applying FBA on the obtained experimental data.

FBA is an informative tool for analyzing carbon/electron distribution and understanding the performance of various $\mathrm{H}_{2}$ producing batches [29]. The list of the reactions, adopted for establishing FBA is given in a previous work [28]. Based on FBA results, we could calculate acetogenic $\mathrm{H}_{2}$ consumption, $\mathrm{H}_{2}$ production by hydrogenase activity, and net $\mathrm{H}_{2}$ production. Figure 5 provides a thorough explanation for $\mathrm{H}_{2}$ production from tested batches. Details regarding the calculations can be found in a previous work [29]. Apparently, a correlation between obtained $\mathrm{H}_{2}$ yield values and $\mathrm{H}_{2}$ production by hydrogenase activity can be noticed. Further, E2 had the highest acetogenic $\mathrm{H}_{2}$ consumption of $0.51 \mathrm{~mol}$ $\mathrm{H}_{2} /$ mol hexose ${ }_{\text {added }}$. This can further support $\mathrm{H}_{2}$ yield results. Then, it can be concluded that both acetogenic $\mathrm{H}_{2}$ consumption and lactate generation are enough for explaining the attained $\mathrm{H}_{2}$ production results.

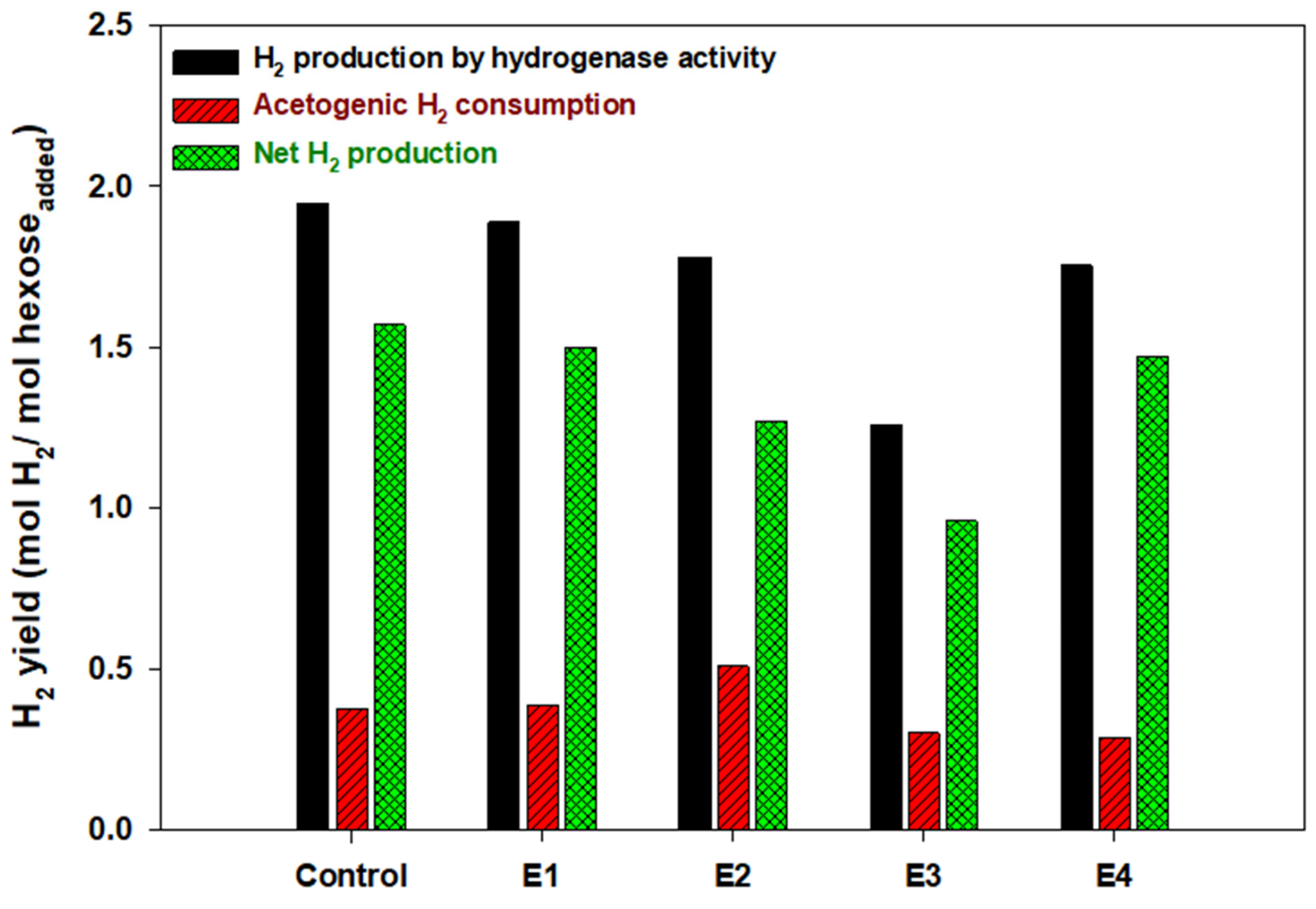

Figure 5. A thorough explanation for $\mathrm{H}_{2}$ production from control $\left(35 \pm 0.1^{\circ} \mathrm{C}\right), \mathrm{E} 1\left(35 \pm 1.5^{\circ} \mathrm{C}\right), \mathrm{E} 2\left(35 \pm 3.0^{\circ} \mathrm{C}\right), \mathrm{E} 3$ $\left(35 \pm 5.0^{\circ} \mathrm{C}\right)$, and $\mathrm{E} 4\left(35 \pm 1.5^{\circ} \mathrm{C}\right)$ batches, using flux balance analysis. 


\subsection{Energy Reduction by Agitation Speed Control}

It was found that the temperature difference at $\pm 1.5^{\circ} \mathrm{C}$ had no significant effect on $\mathrm{H}_{2}$ yield, compared to the control $\left(35 \pm 0.1^{\circ} \mathrm{C}\right)$. Then, the experiment $\mathrm{E} 4$ was performed to compare the energy required for agitation speed during $\mathrm{H}_{2}$ fermentation (Figure 6). The agitation speed was $10 \mathrm{rpm}$ under small temperature difference $\left(< \pm 1.5^{\circ} \mathrm{C}\right)$, while it increased to $100 \mathrm{rpm}$ when the temperature difference between top and bottom of reactor became larger than $\pm 1.5^{\circ} \mathrm{C}$ (Figure 2). When the agitation speed increased to $100 \mathrm{rpm}$, the temperature gap became smaller less than $\pm 1.5^{\circ} \mathrm{C}$ after certain time.

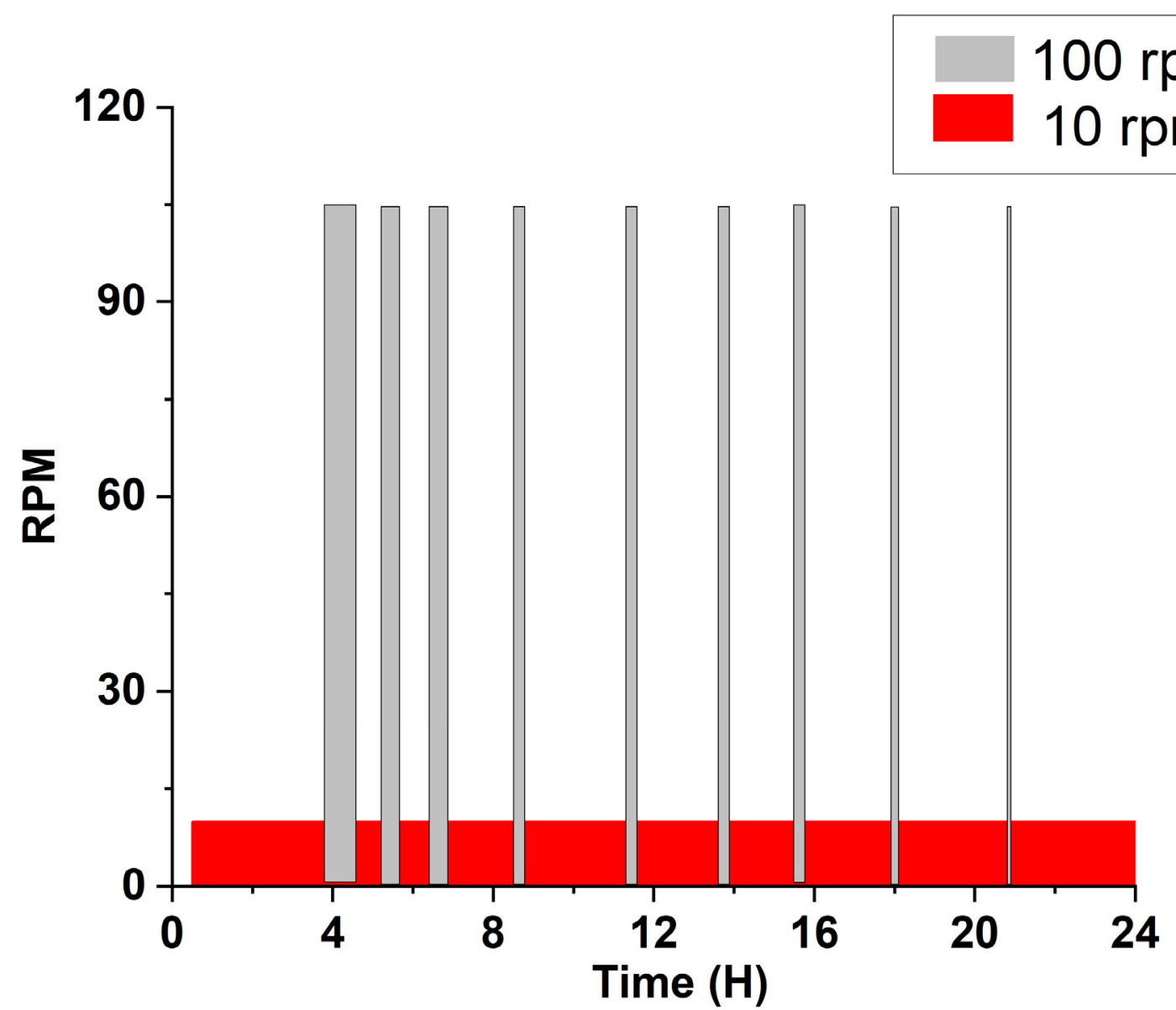

Figure 6. The change in agitation speed during dark fermentation (the agitation speed was $10 \mathrm{rpm}$ under small temperature difference $\left(< \pm 1.5^{\circ} \mathrm{C}\right)$, while it increased to $100 \mathrm{rpm}$ when the temperature gap between top and bottom of reactor became larger than $\left.\pm 1.5^{\circ} \mathrm{C}\right)$.

The $\mathrm{H}_{2}$ yield of $1.47 \mathrm{~mol} \mathrm{H}_{2} / \mathrm{mol}$ hexose added was achieved at $\mathrm{E} 4$ condition, which was almost similar to the control condition $\left(1.50 \mathrm{~mol} \mathrm{H}_{2} / \mathrm{mol}\right.$ hexose $\left.\mathrm{added}\right)$ (Figure $3 \mathrm{~b}$ ). The economic benefit, in terms of the reduction in energy consumption for operating the agitation speed were compared. The control reactor at a fixed rotation of $100 \mathrm{rpm}$ during the temperature difference needed an energy demand of $510 \mathrm{~kJ}(5.9 \mathrm{~W} \times 24 \mathrm{~h} \times 3.6)$, whereas the operational strategy E4 consumed a low energy input of $367 \mathrm{~kJ}$ as it was set up like "10 rpm for $22 \mathrm{~h}$ and $100 \mathrm{rpm}$ for rest of the $2 \mathrm{~h}$ " $=\{(4.1 \mathrm{~W} \times 22 \mathrm{~h}+5.9 \mathrm{~W} \times 2 \mathrm{~h}) \times 3.6\}$. The net energy gain of $28 \%$ has been observed when the rotational speed was reduced from $100 \mathrm{rpm}$ to $10 \mathrm{rpm}$. Figure 6 depicts the time interval for mixing at different rotations per minute for a day in the case of E4. Srirugsa et al. [39] has reported energy gain of $11 \%$ when the rotational speed was reduced from " $100 \mathrm{rpm}$ for $24 \mathrm{~h}$ " mode to " $100 \mathrm{rpm}$ for $8 \mathrm{~h}+10 \mathrm{rpm}$ for rest $16 \mathrm{~h}$ " mode. Moreover, a reduction in mixing speed from $150 \mathrm{rpm}$ to 
$25 \mathrm{rpm}$ resulted in $83 \%$ reduction in equivalent energy consumption, while having same output [40].

In full-scale anaerobic digesters, mixing is not continuous, rather it is intermittent. However, such intermittent mixing was found to be random and irrational. For example, when Zhu et al. [41] reduced the intermittent period from 12 to $4 \mathrm{~h}, \mathrm{H}_{2}$ productivity increased by $4 \%$. On the other hand, reducing the intermittent stirring period from 8 to $2 \mathrm{~h}$, sharply lowered $\mathrm{H}_{2}$ productivity by $30 \%$ [41]. Therefore, regulating intermittent mixing is a must for avoiding drops in $\mathrm{H}_{2}$ production. For efficient mixing regulation, important parameters can be sensed and then used for deciding the intermittent mixing condition. Herein, we proposed sensing the temperature difference as a tool for regulating intermittent mixing.

The target of lowering agitation speed was reducing the energy demand, without affecting the performance. Our results confirmed that $\mathrm{H}_{2}$ production, under low mixing speed or intermittent mixing, has not been significantly affected by such change in mixing. Energy reduction, acquired in this study, can have significant impact when it is upscaled to industrial level.

\section{Conclusions}

The total amount of $\mathrm{H}_{2}$ production declined as the localized temperature gap became larger with the increased lactate production. $\mathrm{H}_{2}$ yield decreased from 1.50 to $0.98 \mathrm{~mol}$ $\mathrm{H}_{2} / \mathrm{mol}$ hexose $e_{\text {added }}$ when the gap increased from $\pm 0.1^{\circ} \mathrm{C}$ to $\pm 5.0^{\circ} \mathrm{C}$ with the lactate concentration increase from 0.2 to $1.8 \mathrm{~g} \mathrm{COD} / \mathrm{L}$. At $\pm 1.5^{\circ} \mathrm{C}$, a similar $\mathrm{H}_{2}$ yield was attained with the control. Operating the bioreactor with differences in agitation speed responding to the localized temperature gap exhibited a similar $\mathrm{H}_{2}$ yield of $1.47 \mathrm{~mol} \mathrm{H}_{2} / \mathrm{mol}_{\text {hexose }}$ added. Through this strategy, it was possible to save $28 \%$ of energy required in agitation but acquiring same amount of $\mathrm{H}_{2}$. This work emphasized the role of temperature in the fermentation process, and it shows temperature could have been a potential point to control energy consumption through agitation in the optimization process.

Supplementary Materials: The following are available online at https://www.mdpi.com/article/ 10.3390/en14216885/s1, Table S1: Energy balance on COD basis and molar conversion for batches under various localized temperature differences.

Author Contributions: Conceptualization, D.-H.K.; methodology, M.-K.L.; software, A.M.; validation, S.I.; formal analysis, M.-K.L.; investigation, S.I., A.M. and O.P.; writing-original draft preparation, S.I., M.-K.L., A.M. and O.P.; writing-review and editing, D.-H.K. and K.-H.L.; visualization, M.-K.L. and A.M.; supervision, D.-H.K. and K.-H.L.; project administration, D.-H.K.; funding acquisition, D.-H.K. All authors have read and agreed to the published version of the manuscript.

Funding: This research was funded by INHA UNIVERSITY, grant number (INHA-65523-01).

Institutional Review Board Statement: Not applicable.

Informed Consent Statement: Not applicable.

Data Availability Statement: Not applicable.

Conflicts of Interest: The authors declare no conflict of interest.

\section{References}

1. Cieciura-Włoch, W.; Binczarski, M.; Tomaszewska, J.; Borowski, S.; Domański, J.; Dziugan, P.; Witońska, I. The use of acidic hydrolysates after furfural production from sugar waste biomass as a fermentation medium in the biotechnological production of hydrogen. Energies 2019, 12, 3222. [CrossRef]

2. Prapinagsorn, W.; Sittijunda, S.; Reungsang, A. Co-digestion of napier grass and its silage with cow dung for methane production. Energies 2017, 10, 1654. [CrossRef]

3. Kieckhäfer, K.; Quante, G.; Müller, C.; Spengler, T.S.; Lossau, M.; Jonas, W. Simulation-based analysis of the potential of alternative fuels towards reducing $\mathrm{CO}_{2}$ emissions from aviation. Energies 2018, 11, 186. [CrossRef]

4. López Ortiz, A.; Meléndez Zaragoza, M.J.; Collins-Martínez, V. Hydrogen production research in Mexico: A review. Int. J. Hydrog. Energy 2016, 41, 23363-23379. [CrossRef] 
5. Da Silva Veras, T.; Mozer, T.S.; da Costa Rubim Messeder dos Santos, D.; da Silva César, A. Hydrogen: Trends, production and characterization of the main process worldwide. Int. J. Hydrog. Energy 2017, 42, 2018-2033. [CrossRef]

6. Islam, M.S.; Guo, C.; Liu, C.Z. Enhanced hydrogen and volatile fatty acid production from sweet sorghum stalks by two-steps dark fermentation with dilute acid treatment in between. Int. J. Hydrog. Energy 2018, 43, 659-666. [CrossRef]

7. Salem, A.H.; Brunstermann, R.; Mietzel, T.; Widmann, R. Effect of pre-treatment and hydraulic retention time on biohydrogen production from organic wastes. Int. J. Hydrog. Energy 2018, 43, 4856-4865. [CrossRef]

8. Boodhun, B.S.F.; Mudhoo, A.; Kumar, G.; Kim, S.H.; Lin, C.Y. Research perspectives on constraints, prospects and opportunities in biohydrogen production. Int. J. Hydrog. Energy 2017, 42, 27471-27481. [CrossRef]

9. Wong, Y.M.; Wu, T.Y.; Juan, J.C. A review of sustainable hydrogen production using seed sludge via dark fermentation. Renew. Sustain. Energy Rev. 2014, 34, 471-482. [CrossRef]

10. Ghimire, A.; Frunzo, L.; Pirozzi, F.; Trably, E.; Escudie, R.; Lens, P.N.L.; Esposito, G. A review on dark fermentative biohydrogen production from organic biomass: Process parameters and use of by-products. Appl. Energy 2015, 144, 73-95. [CrossRef]

11. Urbaniec, K.; Bakker, R.R. Biomass residues as raw material for dark hydrogen fermentation-A review. Int. J. Hydrog. Energy 2015, 40, 3648-3658. [CrossRef]

12. Sivagurunathan, P.; Kumar, G.; Bakonyi, P.; Kim, S.H.; Kobayashi, T.; Xu, K.Q.; Lakner, G.; Tóth, G.; Nemestóthy, N.; Bélafi-Bakó, K. A critical review on issues and overcoming strategies for the enhancement of dark fermentative hydrogen production in continuous systems. Int. J. Hydrog. Energy 2016, 41, 3820-3836. [CrossRef]

13. Kumar, G.; Sivagurunathan, P.; Pugazhendhi, A.; Thi, N.B.D.; Zhen, G.; Chandrasekhar, K.; Kadier, A. A comprehensive overview on light independent fermentative hydrogen production from wastewater feedstock and possible integrative options. Energy Convers. Manag. 2017, 141, 390-402. [CrossRef]

14. Dareioti, M.A.; Vavouraki, A.I.; Tsigkou, K.; Zafiri, C.; Kornaros, M. Dark fermentation of sweet sorghum stalks, cheese whey and cow manure mixture: Effect of PH, pretreatment and organic load. Processes 2021, 9, 1017. [CrossRef]

15. Jiang, F.; Peng, Z.; Li, H.; Li, J.; Wang, S. Effect of hydraulic retention time on anaerobic baffled reactor operation: Enhanced biohydrogen production and enrichment of hydrogen-producing acetogens. Process 2020, 8, 339. [CrossRef]

16. Ohnishi, A.; Hasegawa, Y.; Fujimoto, N.; Suzuki, M. Biohydrogen production by mixed culture of megasphaera elsdenii with lactic acid bacteria as lactate-driven dark fermentation. Bioresour. Technol. 2021, 343, 126076. [CrossRef]

17. Lee, K.S.; Lin, P.J.; Chang, J.S. Temperature effects on biohydrogen production in a granular sludge bed induced by activated carbon carriers. Int. J. Hydrog. Energy 2006, 31, 465-472. [CrossRef]

18. Wang, J.; Wan, W. Effect of temperature on fermentative hydrogen production by mixed cultures. Int. J. Hydrog. Energy 2008, 33, 5392-5397. [CrossRef]

19. Özgür, E.; Uyar, B.; Öztürk, Y.; Yücel, M.; Gündüz, U.; Eroğlu, I. Biohydrogen production by Rhodobacter capsulatus on acetate at fluctuating temperatures. Resour. Conserv. Recycl. 2010, 54, 310-314. [CrossRef]

20. Kress, P.; Nägele, H.J.; Oechsner, H.; Ruile, S. Effect of agitation time on nutrient distribution in full-scale CSTR biogas digesters. Bioresour. Technol. 2018, 247, 1-6. [CrossRef]

21. Lemmer, A.; Naegele, H.J.; Sondermann, J. How efficient are agitators in biogas digesters? Determination of the efficiency of submersible motor mixers and incline agitators by measuring nutrient distribution in full-scale agricultural biogas digesters. Energies 2013, 6, 6255-6273. [CrossRef]

22. Kaparaju, P.; Buendia, I.; Ellegaard, L.; Angelidaki, I. Effects of mixing on methane production during thermophilic anaerobic digestion of manure: Lab-scale and pilot-scale studies. Bioresour. Technol. 2008, 99, 4919-4928. [CrossRef] [PubMed]

23. Lin, P.J.; Chang, J.S.; Yang, L.H.; Lin, C.Y.; Wu, S.Y.; Lee, K.S. Enhancing the performance of pilot-scale fermentative hydrogen production by proper combinations of HRT and substrate concentration. Int. J. Hydrog. Energy 2011, 36, 14289-14294. [CrossRef]

24. Jung, K.W.; Kim, D.H.; Shin, H.S. A simple method to reduce the start-up period in a $\mathrm{H}_{2}$-producing UASB reactor. Int. J. Hydrog. Energy 2017, 36, 1466-1473. [CrossRef]

25. Angelidaki, I.; Sanders, W. Assessment of the anaerobic biodegradability of macropollutants. Rev. Environ. Sci. Biotechnol. 2004, 3, 117-129. [CrossRef]

26. APHA. Standard Methods For the Examination of Water and Wastewater, 21st ed.; Amer Public Health Assn: Washington, DC, USA, 2005.

27. DuBois, M.; Gilles, K.A.; Hamilton, J.K.; Rebers, P.A.; Smith, F. Colorimetric method for determination of sugars and related substances. Anal. Chem. 1956, 28, 350-356. [CrossRef]

28. Chaganti, S.R.; Kim, D.-H.; Lalman, J.A. Flux balance analysis of mixed anaerobic microbial communities: Effects of linoleic acid (LA) and $\mathrm{pH}$ on biohydrogen production. Int. J. Hydrog. Energy 2011, 36, 14141-14152. [CrossRef]

29. Lalman, J.A.; Chaganti, S.R.; Moon, C.; Kim, D.-H. Elucidating acetogenic $\mathrm{H}_{2}$ consumption in dark fermentation using flux balance analysis. Bioresour. Technol. 2013, 146, 775-778. [CrossRef]

30. Mostafa, A.; El-Dissouky, A.; Fawzy, A.; Farghaly, A.; Peu, P.; Dabert, P.; Le Roux, S.; Tawfik, A. Magnetite/graphene oxide nano-composite for enhancement of hydrogen production from gelatinaceous wastewater. Bioresour. Technol. 2016, 216, 520-528. [CrossRef] [PubMed]

31. Mostafa, A.; Im, S.; Song, Y.-C.; Park, J.-H.; Kim, S.-H.; Lim, K.-H.; Kim, D.-H. Unravelling the enhancement of biohydrogen production via adding magnetite nanoparticles and applying electrical energy input. Int. J. Hydrog. Energy 2021. [CrossRef] 
32. Kumar, G.; Park, J.; Kim, M.; Kim, D.-H.; Kim, S. Hydrogen fermentation of different galactose compositions during various hydraulic retention times (HRTs). Int. J. Hydrog. Energy 2014, 39, 20625-20631. [CrossRef]

33. Kim, D.-H.; Kim, S.; Kim, K.; Shin, H. Experience of a pilot-scale hydrogen-producing anaerobic sequencing batch reactor (ASBR) treating food waste. Int. J. Hydrog. Energy 2010, 35, 1590-1594. [CrossRef]

34. Jung, K.W.; Kim, D.-H.; Kim, S.H.; Shin, H.S. Bioreactor design for continuous dark fermentative hydrogen production. Bioresour. Technol. 2011, 102, 8612-8620. [CrossRef] [PubMed]

35. Kim, D.-H.; Han, S.K.; Kim, S.H.; Shin, H.S. Effect of gas sparging on continuous fermentative hydrogen production. Int. J. Hydrog. Energy 2006, 31, 2158-2169. [CrossRef]

36. Bundhoo, M.A.Z.; Mohee, R. Inhibition of dark fermentative bio-hydrogen production: A review. Int. J. Hydrog. Energy 2016, 41, 6713-6733. [CrossRef]

37. Gomes, S.D.; Fuess, L.T.; Mañunga, T.; De Lima Gomes, P.C.F.; Zaiat, M. Bacteriocins of lactic acid bacteria as a hindering factor for biohydrogen production from cassava flour wastewater in a continuous multiple tube reactor. Int. J. Hydrog. Energy 2016, 41, 8120-8131. [CrossRef]

38. Manish, S.; Venkatesh, K.V.; Banerjee, R. Metabolic flux analysis of biological hydrogen production by Escherichia coli. Int. J. Hydrog. Energy 2007, 32, 3820-3830. [CrossRef]

39. Srirugsa, T.; Prasertsan, S.; Theppaya, T.; Leevijit, T.; Prasertsan, P. Appropriate mixing speeds of Rushton turbine for biohydrogen production from palm oil mill effluent in a continuous stirred tank reactor. Energy 2019, 179, 823-830. [CrossRef]

40. Lindmark, J.; Eriksson, P.; Thorin, E. The effects of different mixing intensities during anaerobic digestion of the organic fraction of municipal solid waste. Waste Manag. 2014, 34, 1391-1397. [CrossRef]

41. Zhu, S.; Zhang, Z.; Zhang, H.; Jing, Y.; Li, Y.; Zhang, Q. Rheological properties of corn stover hydrolysate and photo-fermentation bio-hydrogen producing capacity under intermittent stirring. Int. J. Hydrog. Energy 2020, 45, 3721-3728. [CrossRef] 